PLURAL, Revista do Programa de Pós-Graduação em Sociologia da USP, São Paulo, v. 16, n. 2, pp. 9-32, 2009

\title{
A luta pela cidadania no Brasil
}

\section{Lucas Coelho Brandão*}

Democratizar é um verbo reflexivo:

ou a sociedade se democratiza

ou ninguém a democratizará

em lugar dela.

Emir Sader (1987)

Resumo: O Congresso Constituinte de 1987-1988 foi um raro momento na história nacional no qual os movimentos populares participaram de forma significativa na luta política para definir o núcleo de ordenamento jurídico da nação. Apresenta-se aqui um balanço crítico dessa mobilização, debatendo suas implicações e limitaçôes a partir das discussóes teóricas sobre o desenvolvimento da cidadania no Brasil e no mundo.

Palavras-chave: movimentos sociais; Congresso Constituinte de 1987-1988; cidadania; direitos.

\section{The fight for citizenship in Brazil}

Abstract: The Brazilian Constituent General Assembly of 1987-1988 was a rare moment in history where the social movements participated actively and substantially in the political struggle to elaborate the juridical core of the nation. I present here a critical discussion of this mobilization, debating its implications and limitations in dialogue with the theoretical debate on the development of citizenship in Brazil and in the world.

Keywords: social movements; Brazilian Constituent General Assembly of 1987-1988;

citizenship; civil rights.

\footnotetext{
* Mestrando em Sociologia pela Universidade de São Paulo.
} 


\section{INTRODUÇÃO}

Ulysses Guimaráes, presidente do Congresso Nacional Constituinte de 1988, nomeou a nova Carta Magna do país de "Constituiçâo Cidadâ". Era uma alusão aos novos direitos políticos, civis e sociais assegurados com a nova Constituiçáo. $\mathrm{O}$ título entrou para a memória popular, e a cidadania, paulatinamente, tornou-se um valor na nova sociedade democrática. Mas cabe perguntar: que cidadania é essa? Como ela foi construída? Seria ela um conjunto de princípios racionalmente normatizados em prol da nova democracia ou seria, antes, o resultado de diversos embates entre grupos e projetos divergentes, que, entre 1986 e I988, disputaram, sob múltiplas frentes, quais seriam as novas garantias legais?

Dessa forma, toma-se como pressuposto de que a cidadania, aqui como alhures, foi (e ainda é) fruto de lutas sociais. Assim, os sentidos, os caminhos e as consequências nem sempre são claros e muitas vezes são constantemente debatidos pelos atores em disputa. No caso da Constituinte de I988, os movimentos sociais exerceram um papel primordial: o art. 24 do Regimento Interno da Constituinte estabeleceu as chamadas "emendas populares", mecanismo de participaçáo popular no processo constituinte, no qual, por meio de abaixo-assinados, os eleitores poderiam propor diretamente emendas constitucionais (DIÁRIO DA ASSEMBLÉIA NACIONAL CONSTITUINTE, 1987, p. 876).

O objetivo deste artigo é realizar um balanço crítico entre as discussōes teóricas sobre a cidadania no Brasil e no mundo e a luta pela cidadania na Constituinte de 1988, procurando, assim, analisar um momento ímpar na história nacional, em que os movimentos populares participaram (em maior ou menor grau) diretamente da luta política, para definir o núcleo de ordenamento jurídico da nação. Dessa forma, será possível fornecer uma base inicial para realizar uma análise do que representou esse processo, de quais foram suas conquistas e seus limites.

\section{O CONCEITO DE CIDADANIA}

Duas ideias eram essenciais ao status de cidadáo em algumas cidades gregas: a isonomia (igualdade perante a lei) e a isogoria (a igual liberdade de palavra). Embora náo seja o escopo deste trabalho remontar toda a gênese do conceito de cidadania, essas duas ideias gregas vão nortear toda a discussão posterior dos jusnaturalistas e dos teóricos contemporâneos.

A cidadania moderna, tal como a compreendemos atualmente, tem suas origens na formaçáo do Estado de Direito e nas relaçôes específicas entre os ideais de liberdade e de igualdade que prefiguram essa forma política. T. H. Marshall (1967) foi um dos principais intelectuais a se debruçarem sobre o tema. Em seu livro Cidadania, Classe Social e Status, ele parte da análise do desenvolvimento histórico da cidadania na Inglaterra para identificar três dimensôes básicas da cidadania:

a) Direitos Civis: Conquistados no século XVIII, os direitos civis seriam "os direitos necessários à liberdade individual - liberdade de ir e vir, liberdade de imprensa, 
pensamento e fé, o direito à propriedade e de concluir contratos válidos e o direito à justiça" (Marshall, 1967, p. 63). Para o autor, os Tribunais de Justiça desempenhariam um papel crucial na garantia dos direitos civis.

b) Direitos Políticos: Conquistados no século XIX, os direitos políticos estáo relacionados "à participação no exercício do poder político, como membro de um organismo investido de autoridade política ou como um eleitor dos membros de tal organismo. As instituiçóes correspondentes são o Parlamento e os conselhos do governo local" (Marshall, 1967, p. 63). Dessa forma, algumas das questóes disputadas seriam o acesso às instituiçóes políticas, os direitos eleitorais (e a luta pela expansão do sufrágio), o voto secreto, a permissão de novos partidos políticos, entre outras.

c) Direitos Sociais: Conquistados (em geral apenas parcialmente) ao longo do século $\mathrm{XX}$, os direitos sociais se referem:

a tudo o que vai desde o direito a um mínimo de bem-estar econômico e segurança até o direito de participar, por completo, da herança social e levar a vida de um ser civilizado, de acordo com os padrōes que prevalecem na sociedade. As instituições mais ligadas a eles são o sistema educacional e os serviços sociais (MARSHALL, 1967, p. 64).

Um marco do desenvolvimento dos direitos sociais é o surgimento do Sistema de Bem-Estar Social no pós-guerra, disseminando alguns direitos, como seguro-desemprego, seguro-doença, pensão, previdência, etc.

Segundo Marshall, a luta pela extensão da cidadania está relacionada à correção da insuficiência da igualdade perante a lei (garantida teoricamente pelos direitos civis), face à estratificação social, sendo, assim, o principal meio político para resolver, ou ao menos conter, as contradiçóes entre a igualdade política formal e a persistência da extensiva desigualdade social e econômica oriunda, em última instância, do caráter do mercado capitalista e da existência da propriedade privada.

De fato, Quirino e Montes (1986, p. 59) apontam para a importância, no que se refere a uma cidadania plena, não só dos direitos dos cidadãos, mas também de seus deveres:

[...] através desses direitos [políticos] os cidadáos se tornam responsáveis pela organizaçáo do poder, de tal forma que sua participaçáo, por meio dos vários sistemas de representação e dos vários tipos de escolha que podem realizar, lhes dá uma percepção de si próprios como artífices do próprio Estado, em igualdade de condiçôes com relaçáo a todos os demais.

De certa forma, após Marshall, a grande maioria dos autores que discorreram sobre a cidadania o fizeram a partir de sua teoria, seja complementando-a, seja criticando-a. Uma das 
críticas mais recorrentes é a de que Marshall elabora uma perspectiva evolucionista da emergência histórica da cidadania, visão segundo a qual os direitos sociais aparecem como efeito de um amplo e iminente desenvolvimento no interior da sociedade (TURNER, I994, p. 202)1.

Segundo Bryan Turner, o conceito unitário de cidadania de Marshall, além de evolucionista, é etnocêntrico: o desenvolvimento e a expansão dos direitos, encadeados historicamente e logicamente na análise de Marshall, seriam válidos apenas para o caso britânico; a luta pelos diferentes tipos de direitos teria suas particularidades em cada país. Dessa forma, o autor cria uma tipologia com base em duas variáveis cruciais: I) a natureza passiva ou ativa da cidadania (desenvolvida de cima para baixo, por meio do Estado; ou de baixo para cima, por meio de instituiçóes participativas locais, como sindicatos); 2) definiçóes públicas ou privadas da atividade moral, refletidas na criaçáo (ou náo) de um espaço público de atividade política.

Sua análise histórica enquadraria a tradição revolucionária francesa na intersecção entre uma cidadania criada de forma ativa (de baixo para cima) e a criaçáo de espaços públicos; já o caso inglês seria a junçáo de uma cidadania criada de forma passiva (de cima para baixo) com a construção de espaços públicos; o liberalismo americano teria engendrado uma cidadania que, apesar de ser ativa (de baixo para cima), é fundada em uma moral individualista, sem a criaçáo de espaços públicos como bastióes de uma moralidade comum². Finalmente, o caso alemáo uniria uma cidadania constituída passivamente (aqui, fruto principalmente da açáo do Estado, visto como a única fonte de autoridade pública), com uma ênfase na dimensão privada (favorecendo a família, a religiáo e o desenvolvimento ético individual) - no extremo, esse desenvolvimento típico da Alemanha abriria caminho para o fascismo.

A tipologia de Turner complementa em pontos essenciais a definiçáo de cidadania de Marshall. Cabe, para os efeitos deste trabalho, destacar que o autor vai além da análise de Marshall acerca do que é, concretamente, cada tipo de direito que compóe, em conjunto, o que chamamos de cidadania.

Turner incorpora à definiçáo de cidadania o próprio processo de construçáo/conquista dela, indicando que, nos países onde a cidadania foi conquistada pela luta dos grupos da sociedade civil, sua natureza daí decorrente possui um sentido social diverso da cidadania definida pelas elites políticas.

Como em qualquer tipologia, vale sempre reforçar a compreensão weberiana de "tipos ideais", próprios para oferecer pontos de referência a uma análise comparativa com a realidade

I Turner afirma que, segundo Anthony Giddens, os direitos de cidadania não são um conjunto de arranjos sociais unificado e homogêneo. Os direitos liberais, fruto das lutas da burguesia, não podem ser comparados com as demandas por um sistema de bem-estar social, oriundas das lutas dos socialistas e de outras formas de ação do proletariado. Além disso, não existe um paralelismo necessário, ou até um desenvolvimento necessário, dos três tipos de direitos. Por exemplo, os direitos civis podem ser desenvolvidos no capitalismo sem o desenvolvimento de uma cidadania política. Giddens afirma também que Marshall náo considerou que o desenvolvimento do sistema de bem-estar social está inserido em um contexto mais amplo da guerra e da reconstrução do pós-guerra.

$2 \mathrm{O}$ político é visto, nos Estados Unidos, como moralmente suspeito: "To some extent the dominance of individualism and the value of personal success have meant that the 'public arena' is typically in terms of individual involvement in local voluntary associations" (TURNER, 1994, p. 218). 
empírica, sempre mais ambígua e complexa. Uma pergunta pertinente a este trabalho é saber até que ponto a luta por direitos civis, políticos e sociais na Assembleia Nacional Constituinte brasileira logrou romper com a dinâmica passiva presente (ao menos parcialmente), em alguns fatos históricos nacionais (como a Independência, a promulgação da Lei Áurea e, em seguida, a da República, entre outros).

Veremos, mais adiante, que alguns fatos alteraram significativamente essa dinâmica ao longo da Constituinte, mas não sem uma reação das elites e uma limitação também significativa da participaçãoo popular.

Outra crítica possível às teorias da cidadania existentes, a de Turner inclusa, é de que o papel do Estado na formulação (e na reproduçáo) dos diferentes tipos de cidadania ainda é secundário. As dinâmicas e as estruturas dos diferentes Estados ainda não foram suficientemente exploradas pelas teorias vigentes, especialmente se considerarmos a centralidade dessa estrutura política para a construçáo e para a garantia dos direitos.

O Estado, em Turner, paira sobre a dinâmica social dos dominantes e dos dominados, assim como sobre a moralidade própria de cada cultura. Dessa forma, é possível que uma análise mais detalhada sobre o papel exercido por agentes e instituiçóes do Estado em momentos-chave da luta pela cidadania (como a Constituinte) possa contribuir para uma compreensão maior da influência desses atores, assim como de seus interesses específicos e, inclusive, das contradiçóes presentes na atuação das diferentes instituiçôes estatais.

\section{CIDADANIA NO BRASIL}

Apesar dos avanços da tipologia de Turner, ela, no entanto, ainda mantém uma visão etnocêntrica, sendo, portanto, ainda insuficiente para uma teoria global da cidadania. Mesmo se compreendermos as dimensóes (ativa-passiva e público-privado) como "tipos ideais", ela permanece insuficiente para uma análise da América Latina e, especialmente, do complexo arranjo brasileiro constituído ao longo do século XX.

Uma importante contribuição nesse sentido é a obra de Jessé Souza, $A$ Construção Social da Subcidadania, na qual ele procura demonstrar que, se nas sociedades centrais a formação do self pontual ${ }^{3}$ como padráo cultural e intelectual foi anterior às suas práticas institucionais e sociais, nas sociedades periféricas, as práticas já chegam de forma institucionalizada, sem serem precedidas por ideias que as embasassem.

Dessa forma, inexistiria aqui a mesma esfera moral articulada, generalizada e consensual presente na América do Norte e na Europa, como, por exemplo,

\footnotetext{
3 O self pontual é, segundo Souza (2003, p. 3I), uma forma de reconhecimento social de caráter universalizante e caracterizada pelo princípio da dignidade; o self pontual é a "concepção contingente e historicamente específica de ser humano, presidido pela noçáo de calculabilidade, raciocínio prospectivo, autocontrole e trabalho produtivo como os fundamentos implícitos, tanto da sua auto-estima quanto do seu reconhecimento social".
} 
o consenso [valorativo] acerca da necessidade de homogeneização social e generalização de tipo de personalidade e de economia emocional burguesa a todos os estratos sociais. [...] Em todos os países que lograram homogeneizar um tipo humano transclassista, este foi um desiderato perseguido de forma consciente e decidida e não deixado a uma suposta ação automática do progresso econômico (SouZA, 2003, p. 99).

Com a Abolição da Escravatura, acompanhada do abandono dos ex-escravos à própria sorte (sem acesso à terra, com a Lei de Terras de I850), aliado ao estímulo à imigração europeia, o capitalismo brasileiro fez dos ex-escravos e dos agregados/dependentes pessoais uma ralé estrutural caracterizada por um "habitus precário" 4 . Por meio da ideologia do desempenhos (propriamente moderna e capitalista), somada à ideologia da democracia racial, a inadaptação dessa ralé estrutural e a consequente marginalização seriam percebidas como fracasso pessoal, obscurecendo as causas da desigualdade e a hierarquia valorativa implícita.

Assim, segundo Jessé Souza, nos países capitalistas periféricos e, principalmente, no Brasil, o processo de modernização (com a construção de instituições capitalistas como o "Mercado" em I808, o "Estado" em I822 e a "Indústria" a partir de 1930) náo foi acompanhado de um consenso mínimo acerca das ideias (e de uma gramática social universalista), que, em outras partes, permitiram e/ou facilitaram construir toda uma luta pela extensão da cidadania. Aqui, as práticas vieram antes das ideias e, nesse processo, construiu-se socialmente toda uma parcela da populaçáo alijada da cidadania plena e, portanto, da herança social da civilizaçáo moderna. Essa subcidadania seria a marca da ralé estrutural na periferia do capitalismo.

A análise de Souza é similar à de outros teóricos como Francisco Weffort e José Álvaro Moisés. Para eles, formou-se no Brasil um sistema dual, em que, de um lado, existe um regime liberal de oligarquias competitivas e, do outro, uma massa dos “marginais” e dos não organizados. Weffort (apud MoIsÉs, I990, p. 32) pondera que "existem dezenas de milhóes de pessoas que são cidadãos, no sentido político-formal da expressão, mas que não têm condições de exercer a cidadania”. Já Moisés (I990, p. 32) complementa a análise sobre essa "massa marginal" afirmando que:

Não se trata apenas do fato de que, em relação a esses contingentes da população, os mecanismos da democracia representativa - como as eleiçóes periódicas e a participação em partidos - são limitados, comprometendo a eficácia do princípio da soberania

\footnotetext{
4 É uma ralé inadaptada às condiçóes da modernidade, às disposiçóes de comportamento de trabalho capitalista, de autocontrole, assim como marcada pela ausência de um código moral de conduta (regida por um código de honra). Inadaptaçáo agravada pelo repúdio a todas as formas manuais de trabalho que lembravam a escravidáo, assim como pela desorganização da família e pelo alcoolismo. Esse habitus precário existe em grupos restritos nas sociedades centrais, mas "só ganha estatuto de fenômeno de massa permanente em países periféricos, como o Brasil" (SouzA, 2003, p. 167). 5 Souza utiliza a ideia de ideologia do desempenho de Pierre Bourdieu, para quem seria ela a responsável, no mundo moderno, pela percepção, por parte dos indivíduos, da dominaçáo como algo natural, uma consequência direta dos próprios esforços (méritos ou deméritos); não se perceberia, portanto, que o mérito (assim como a dominaçáo que ele legitima) é produzido socialmente, sendo consequência não de escolhas individuais autônomas, mas sim, principalmente, de escolhas sociais pré-reflexivas, naturalizadas de acordo com o habitus ao qual pertence o indivíduo.
} 
popular no conjunto do sistema político; trata-se de que esses setores sequer têm um acesso efetivo a esses próprios mecanismos.

Segundo José Maria dos Santos (1930), outro fator importante de limitaçáo ao desenvolvimento de uma cidadania ativa no Brasil é o modelo republicano que aqui se instaurou com base nos postulados positivistas de um poder federal concentrado e forte. Moisés (I990, p. II) afirma, assim:

O advento da república brasileira, portanto, ao contrário da experiência norte-americana, não realizou a centralização dos recursos de poder em mãos do Estado junto com a preservação democrática dos poderes locais, nem criou mecanismos de contrapeso que pudessem equilibrar a concentração de poder entregue ao Executivo; menos ainda serviu para valorizar as instituiçóes de representaçáo ou para criar mecanismos republicanos que operem a distinção entre os interesses públicos e os privados.

\section{REDEMOCRATIZAÇÃO E A LUTA PELA CIDADANIA}

Dois pontos de inflexão na história da cidadania no Brasil são o longo período de suspensão de grande parte dos direitos civis, políticos e sociais, durante o regime militar, e a década que antecedeu a promulgaçáo da Constituiçáo de 1988, caracterizada pela intensificaçáo da luta contra o golpe militar e por novos direitos. Das grandes greves de Sáo Bernardo do Campo em 78, 79 e 80, decorreu a reorganização do sindicalismo, resultando na fundação, em 28 de agosto de 1983 , da Central Única dos Trabalhadores (CUT). Em I983 e 84, a insatisfaçáo social com o regime militar e com a crise econômica foi canalizada na Campanha das Diretas, que, embora tenha visto a Emenda Dante de Oliveira ser derrubada, teve enorme impacto político no país - mais de cinco milhôes de pessoas saíram às ruas para participar da maior manifestação de massas na história brasileira. No ano seguinte, com a eleição (indireta) do primeiro presidente civil desde 1964, ganhou força a mobilização e a intensa disputa política e social em prol de uma nova Constituição democrática.

Nesse processo, os movimentos sociais vão conquistar, pela primeira vez na história nacional, um destaque significativo na luta pela cidadania. Quirino e Montes (1987, p. 80) ressaltam a importância desse fato político novo:

O fechamento do sistema político e dos canais tradicionais de participaçáo, de reivindicaçáo e de representaçáo trouxe consigo a emergência, nos movimentos sociais, de uma nova consciência de direitos a serem reivindicados, coletivamente, em oposição aos favores a serem pedidos, e isso constitui um fato político novo, dos últimos dez anos, em toda a história brasileira, enquanto experiência de massa. 
Emir Sader (1988), em Quando Novos Atores Entram em Cena, ao discorrer sobre os movimentos populares do período entre 1978 e I985, destaca a importância das questóes do cotidiano, compreendidas como expressóes de resistência, autonomia e criatividade, transformando-as em eixos da luta política. Assim, os movimentos populares passaram a reivindicar novos direitos relacionados às questóes de moradia, educação, saúde, trabalho, lazer e dos direitos da criança e do adolescente, entre outros.

O autor afirma, assim: "A novidade eclodida em 1978 foi primeiramente enunciada sob a forma de imagens, narrativas e análises referindo-se a grupos populares os mais diversos que irrompiam na cena pública reivindicando seus direitos, a começar pelo primeiro, pelo direito de reivindicar direitos" (SADER, I988, p. 26).

Com o início das mobilizaçóes em torno da convocaçáo de uma Constituinte, surgiu uma polêmica que perduraria até a promulgaçáo da nova Carta Magna. O governo Sarney, em vez de propor a eleiçấo de uma Assembleia (unicameral) Constituinte exclusiva, decidiu conceder poderes constituintes ao Congresso a ser eleito em is de novembro de 1986.

Em meio a essa disputa, surgiu uma das primeiras açōes de envergadura da sociedade civil: os movimentos sociais organizaram uma campanha por uma Constituinte exclusiva, enviando cerca de setenta mil telegramas e cartas destinados ao deputado Flávio Bierrenbach, relator da Comissáo Mista encarregada de dar parecer ao projeto de convocaçáo da Assembleia Nacional Constituinte (Projeto de Emenda Constitucional de 28 de junho de 1985).

No dia Is de outubro, o relator surpreendeu o governo ao propor a realizaçáo prévia de um plebiscito para que o povo decidisse sobre as questôes mais polêmicas: uma Constituinte congressual ou exclusiva; a coincidência ou não da eleição constituinte com a dos governadores; o funcionamento de uma comissão legislativa simultânea à Constituinte; e a coleta de sugestôes para a Constituinte por meio das Câmaras Municipais.

O governo e a liderança do PMDB derrubaram eventualmente o parecer do relator, aprovando o substitutivo do deputado Valmor Giavarina - a emenda constitucional foi finalmente promulgada no dia 27 de novembro de 1985 . Em vez de eleger uma Assembleia (unicameral) Constituinte exclusiva, conceder poderes constituintes ao Congresso a ser eleito em I5 de novembro de 1986 -, que acumulou, portanto, a dupla função: legislativa-ordinária e constituinte, assim como perpetuou, nos trabalhos de elaboração da nova Magna Carta, a estrutura bicameral e as distorçôes eleitorais na proporcionalidade dos representantes em cada estado.

Apesar da derrota, o episódio serviu para vislumbrar a capacidade de mobilizaçáo da sociedade civil em torno da Constituinte. Ao longo de 1985 e 1986, não foram poucas as manifestaçôes em defesa de maior participação da sociedade no processo de redemocratizaçáo e de elaboração da nova Constituição.

Dom Paulo Evaristo Arns afirmou, em 1985 (p. 70): 
Se queremos que nossa gente simples aceite a próxima Carta Magna como sendo sua, impóem-se, no mínimo, duas condiçóes: a primeira, que ela tenha origem na própria vontade do povo, alertado para a importância do assunto. Depois, que o mesmo povo possa propor os tópicos que mais influem na sua vida. Além disso, a nação como tal quer asseguradas as medidas que lhe possibilitem a tutela da nova Constituição.

De forma similar, em um colóquio realizado no ano seguinte, João Almino de Souza (I987, p. 8I) avaliou que:

[...] da organização da sociedade e da possibilidade de mobilização da população antes da constituinte e durante esta depende o controle popular sobre as decisóes governamentais e a capacidade de controle e vigilância da Constituinte pela sociedade. A representação não elimina a necessidade desse controle e vigilância, pois, mesmo que desejemos uma Constituinte soberana, devemos estar também atentos para o fato de que toda soberania ilimitada, de quem quer que seja e independentemente de em nome de quem se exerça, pode ser fonte de tirania.

Dessa disputa por uma Assembleia Constituinte livre, exclusiva e soberana, diversos grupos da sociedade civil começaram a se organizar para influir nos rumos dos acontecimentos. Uma novidade importante foi a criaçáo de organizaçóes sociais voltadas diretamente para a Constituinte.

Segundo Michiles et al. (1989), essa mobilização teve duas matrizes: uma no Rio de Janeiro, com o lançamento do Movimento Nacional pela Constituinte, em um ato público com cerca de sete mil pessoas em Duque de Caxias, no dia 26 de janeiro de I985; e outra matriz em São Paulo, com a criação do Plenário de Sáo Paulo Pró-Participaçáo Popular na Constituinte, no dia 6 de fevereiro de 1985 .

Enquanto o Movimento Nacional pela Constituinte tinha como objetivo primordial o resgate da cidadania e a construçáo pelo povo da democracia, a iniciativa paulista focava, inicialmente, a questáo dos instrumentos de participação popular que poderiam ser incluídos na nova Constituição.

O movimento criado no Rio de Janeiro se desenvolveu através de viagens e contatos de seus líderes e organizadores em todo o Brasil, estimulando as iniciativas existentes ou despertando novas. Em São Paulo adotou-se o método da publicação sistemática de um pequeno boletim de notícias, enviado às pessoas e entidades que se interessassem em recebê-lo, em todo o Brasil. Os dois métodos se completavam: os que viajavam incentivavam o engajamento, que, em seguida, era aprofundado, ligando-se às propostas veiculadas nos boletins (Michiles et al., I989, p. 4I). 
Dessa forma, nessa primeira etapa, o Movimento Nacional pela Constituinte estimulava a criaçáo de movimentos constituintes municipais, nos quais o povo elaboraria sua própria proposta paralela de Constituição, levando-a para fóruns estaduais e, depois, para um fórum nacional. Já os Plenários e Movimentos Pró-Participaçâo Popular na Constituinte procuravam articular as entidades e os militantes em prol do objetivo comum de garantir a participaçáo popular no processo constituinte.

De fato, os movimentos populares em torno da Constituinte tiveram diversas facetas, origens, estruturas e composiçôes. Autores como Whitaker, Michiles e Coelho afirmam que, no entanto, apesar da diversidade, esses movimentos

tinham em comum, de maneira geral, uma preocupação suprapartidária, ainda quando nasciam de iniciativas partidárias. Surgiram pela atuação de militantes políticos ou sindicais, de agentes de pastoral, de movimentos de moradores, de associaçôes profissionais. Uns contaram com apoio e ajudas institucionais, de governos, universidades ou igrejas. Outros buscaram sua ação somente em recursos próprios (Michiles et al., 1989, p. 38).

Entre 1985 e 1988, os movimentos sociais envolvidos com a Constituinte passaram por inúmeras transformaçóes, seja nas pautas, em seus repertórios de açôes coletivas 6 , seja na própria composiçấo de militantes. Segundo os relatos dos militantes, apesar da alta rotatividade, existia um núcleo de militantes que persistiam e que serviam de base para novas ondas de mobilizaçóes (Cf. Michiles et al., 1989, p. 39).

A discussão sobre o Regimento Interno da Constituinte, polarizada principalmente pela polêmica sobre a soberania e o funcionamento exclusivo ou paralelo do Congresso, possibilitou aos movimentos uma conquista inédita de mecanismos de participaçáo popular já no processo constituinte. Dessa forma, o art. 24 do Regimento Interno da Constituinte estabeleceu as chamadas "emendas populares":

Fica assegurada, no prazo estabelecido no artigo anterior, a apresentaçáo de proposta de emenda ao Projeto de Constituiçáo, desde que subscrita por $\mathbf{3 0 . 0 0 0}$ (trinta mil) ou mais eleitores brasileiros, em lista organizada por, no mínimo, 3 (três) entidades associativas, legalmente constituídas, que se responsabilizarão pela idoneidade das assinaturas [...] (Diário da Assembléia Nacional Constituinte, 1987, p. 876).

$6 \mathrm{O}$ conceito de "repertório de ações coletivas" foi elaborado inicialmente por Charles Tilly em 1978, com o objetivo de representar o conjunto limitado de formas de ação e estratégias utilizadas por diferentes grupos ou indivíduos para efetuarem as suas demandas: "o repertório não é só o que as pessoas fazem quando elas têm uma demanda; mas é também o que elas sabem como fazer e o que a sociedade passou a esperar que elas escolham fazer dentro de um conjunto de opçôes sancionado culturalmente e limitado empiricamente" (TilLY apud TARROW, 1995, p. 9I). 
O mecanismo das emendas populares contribuiu significativamente para aumentar a mobilização popular por novos direitos: "Só a partir da conquista da emenda popular como instrumento se começou a vincular mais estreitamente o trabalho de mobilizaçâo popular com o que efetivamente ocorria dentro da Constituinte" (Michiles et al., I989, p. 42). Dessa forma, com os instrumentos de participaçáo popular no próprio processo constituinte, gerou-se uma nova Estrutura de Oportunidades Políticas ${ }^{7}$ para os setores e movimentos sociais, possibilitando uma interferência direta das organizaçóes populares no processo constituinte. Além disso, o instrumento das "emendas populares" funcionou como um fator agregador dos diferentes atores e organizaçóes com interesses diversos: as entidades procuraram se articular com outros movimentos com temáticas similares para, assim, criar consensos e apresentar conjuntamente emendas dos mesmos temas.

Apesar das articulaçóes, estimuladas pela própria exigência do Regimento Interno, que impunha a condiçấo de que três entidades associativas se organizassem e se responsabilizassem por cada emenda, algumas divergências entre os movimentos marcaram algumas emendas. Em geral, muitas das divergências decorriam de avaliaçóes conflitantes acerca de qual era o papel e o alcance das emendas populares:

Havia os que propugnavam, como mais importante, a marcação de posiçóes mais radicais, desconsiderando a possibilidade de sua assimilaçáo pela Constituinte, apesar de sua conhecida correlação de forças. Outros, da tendência "realista", como se autodenominaram, ponderavam sobre a necessidade de avançar com propostas progressistas, sem transigir nos pontos fundamentais, mas nunca perdendo de vista o perfil conservador majoritário dos parlamentares ou descurando-se da busca de possíveis alianças (MicHILEs et al., 1989, p. 92).

Alguns exemplos de ruptura foram o da Saúde (com a polêmica sobre o relacionamento do setor público com o privado), o da questáo indígena (com a divergência em torno da abordagem inicial sobre populaçôes indígenas versus naçôes), o da Democratizaçấo da Comunicação (sobre a questáo da exploração dos veículos de comunicação por fundaçôes ou sociedades sem fins lucrativos), o do Movimento Criança e Constituinte (com a questão da idade para admissáo ao trabalho) e da Reforma Agrária e Política Agrícola (o Movimento dos Trabalhadores Rurais Sem Terra apresentou outra emenda, com três novas reivindicaçóes demandadas por sua base).

7 O conceito de Estrutura de Oportunidades Políticas foi elaborado por Charles Tilly, em From Mobilization to Revolution (1978). Para o autor, é necessário sempre analisar o conjunto de oportunidades e ameaças presentes no mundo que cerca o movimento/indivíduos e que tem alguma probabilidade de afetar o bem-estar e o sucesso dos atores. Dessa forma, do lado da oportunidade, deve-se identificar a extensão da vulnerabilidade de outros grupos (incluindo governos) em relaçáo a novas demandas que poderiam, se bem-sucedidas, aumentar a realizaçáo dos interesses do contestador. Já do lado das ameaças, é preciso atentar em que medida outros grupos ameaçam realizar demandas que, se bem-sucedidas, irão reduzir a realização dos interesses do contestador (Cf. TiLLY, 1978, p. 133). 
Mesmo assim, o saldo final da mobilizaçáo popular foi impressionante: duzentas e oitenta e oito entidades diferentes apresentaram cento e vinte e duas emendas populares que angariaram um total de I2.265.854 assinaturas. Considerando que cada eleitor pode subscrever até três emendas, entre $6 \%$ e i $8 \%$ dos eleitores da época assinaram alguma emenda 8 .

Michiles et al. (1989) dividiram as emendas segundo os perfis das entidades que as patrocinavam. Segundo os autores, as vinte e cinco entidades religiosas tiveram o melhor desempenho relativo: $77,6 \%$ de suas emendas tiveram mais de trinta mil assinaturas e, entre as sete emendas apresentadas com mais de quinhentas mil assinaturas, cinco delas tinham o apoio do segmento religioso. Já o segmento patronal conseguiu superar a barreira inicial em dezenove das vinte emendas que propôs, mas apenas uma delas teve mais de quinhentas mil assinaturas. As entidades sindicais foram as mais volumosas: as cento e vinte e uma entidades apresentaram sessenta e duas emendas, sendo que quarenta e duas delas superaram as trinta mil assinaturas, e quatro tiveram mais de quinhentas mil assinaturas.

Além desses grupos, os autores identificaram o das "entidades civis" (com destaque para o fraco desempenho do movimento estudantil: apenas uma das cinco emendas propostas por ele obteve mais de cem mil assinaturas) e o grupo das entidades ligadas aos poderes executivos e legislativos.

Cabe ressaltar que o mecanismo de emendas populares, apesar de ter sido utilizado principalmente pelos movimentos e entidades sociais "progressistas", também foi empregado pelas entidades empresariais e patronais em prol de interesses "conservadores" (Cf. Michiles et al., I989, p. II4). Um exemplo é a Emenda no. o98, apresentada pela Sociedade Rural Brasileira para se contrapor às emendas da ConTAG e do MST; ela obteve 43.275 assinaturas em prol de um projeto conservador de reforma agrária.

Dessa forma, existe uma relaçáo essencial entre os mecanismos de participaçáo popular na Assembleia Nacional Constituinte e a luta pela cidadania que ali se instaurou. De fato, com o desenrolar dos trabalhos constituintes e com o crescimento da mobilizaçáo (lastreado nas emendas populares), o mecanismo serviu não apenas para levar as demandas da sociedade civil para o centro do poder, mas também, de forma inversa, para levar a própria disputa para dentro da sociedade civil, relembrando o pensador italiano Antonio Gramsci, que compreendia a sociedade civil como o conjunto de relaçóes ideológicas-culturais e para quem a esfera da superestrutura poderia ser dividida em dois grandes níveis: a sociedade civil (como conjunto de organismos chamados "privados") e o nível da sociedade política ou do Estado. Enquanto o primeiro teria uma função de produtor de "hegemonias", o segundo produziria a "dominação direta"; ambos formariam uma unidade dialética.

8 Segundo o Anuário Estatístico do IBGE (Instituto Brasileiro de Geografia e Estatística), o número total de eleitores cadastrados para as eleiçóes de 1986 foi de 69.166.810. Dessa forma, se cada cidadáo tivesse assinado três emendas, teríamos 4.088.6I8 eleitores assinantes ( $6 \%$ do eleitorado); no outro extremo, se cada cidadáo tivesse assinado apenas uma emenda, teríamos I2.265.854 eleitores assinantes (I8\% do eleitorado). 
Assim, a sociedade civil também seria um espaço de disputa, de conflito ideológico e cultural que produziria hegemonias. Os mecanismos de participação popular, já no processo constituinte, possibilitaram à sociedade civil interferir diretamente nos trabalhos e na dinâmica constituinte e, assim, intensificar os laços que interligam a sociedade política com a civil.

O controle e a pressão social exercida cotidianamente sobre os deputados constituintes fizeram com que a disputa ideológica, cultural e por questôes/pautas concretas no âmbito da sociedade civil se desse não somente durante o período eleitoral, mas também ao longo de todo o processo de elaboraçáo e negociação da nova Carta Magna.

Dessa forma, a disputa pela produção de hegemonias na sociedade civil se tornou um instrumento e o caminho da própria disputa política no interior da Assembleia Nacional Constituinte. As sucessivas caravanas a Brasília, os debates com representantes dos movimentos sociais e as reuniốes de negociaçáo aos poucos se incorporaram à rotina da Assembleia Nacional Constituinte.

No entanto, alguns autores como Quirino e Montes (1987), apesar de apontarem para a importância das reivindicaçóes por novos direitos que aspirem a uma sociedade mais igualitária, atentam para os riscos que essas mesmas reivindicaçóes podem trazer, especialmente nos casos em que a nova consciência de direitos trouxer um conjunto de reivindicaçóes particularistas e construir um modelo de cidadania unilateral e, em última instância, corporativista.

Em outras palavras, haveria o risco de que, acentuando-se na cidadania apenas o aspecto dos direitos que essa condiçấo assegura, se acabasse por identificar no Estado, numa nova e sofisticada versão do populismo, apenas uma fonte provedora inesgotável, da qual incessantemente são cobradas garantias de liberdades específicas que facilmente poderiam converter-se em uma forma moderna de privilégios. [...] é preciso não esquecer que, transformando-se a defesa dessa igualdade bem como de sua garantia num processo incessantemente renovado de cobrança unilateral do Estado, isso permitiria ao próprio Estado estender sua esfera de ação muito além do previsto ou sequer do desejado (Quirino; Montes, 1987, pp. 8I-82).

A soluçáo seria a construção de reivindicaçóes bilaterais, com direitos garantidos pelo Estado, mas também com deveres impostos aos cidadãos, como a fiscalização do governo e a participação autônoma na vida social e política.

Em um país marcado historicamente por relaçóes de poder hierarquizadas e profundamente centralizadas, nas quais o senhor de terras tinha poder "de vida ou morte" sobre seus escravos e agregados, o modelo corporativista predominou na estrutura sindical, o povo esteve alijado da grande maioria dos acontecimentos históricos, é crucial questionar quais foram os fatores que possibilitaram que, ao longo das lutas que envolveram a Constituinte, os movimentos populares tenham conseguido se mobilizar e criar um ciclo de protestos ${ }^{9} \mathrm{em}$ prol de novas conquistas e,

9 Segundo Sidney Tarrow, os ciclos de protesto canalizam e absorvem as inovaçôes do repertório de açôes contenciosas produzidas em momentos de grande efervescência social; para o autor, as principais características dessas ondas de 
especialmente, de novos direitos. Igualmente importante é investigar quais foram os limites dessa participação, assim como quais foram suas consequências e conquistas.

Axel Honneth, em Lutar por Reconhecimento, teoriza sobre as pré-condiçôes sociais e psicológicas para a ação social transformadora, interligando a dimensão da luta pela cidadania a um contexto mais amplo de transformação da estrutura e dos padrōes de racionalização e socialização na sociedade moderna (Cf. HonNETH, 2003, pp. II7-29I). Assim, a luta pelo reconhecimento é a luta pela constituição de sujeitos históricos, sendo que, para Honneth, um sujeito social precisa se reconhecer como portador de direitos e vontades, o que envolve desde o desenvolvimento da autoconfiança nas relaçôes familiares, o autorrespeito na relação entre os indivíduos e a sociedade (proporcionado pela gramática universalista do direito, permitindo sua constituiçáo individual independentemente de suas opçóes morais) e até o desenvolvimento da autoestima na luta pelo reconhecimento social (em uma comunidade de valores) de determinadas propriedades e atributos relativos ao grupo social ao qual o indivíduo pertence.

Esse reconhecimento social e individual seria uma pré-condiçấo para o desenvolvimento da autonomia necessária para a participação na vida pública e, portanto, para a própria mobilizaçáo transformadora dos indivíduos.

De certa forma, o processo de construçáo da mobilizaçáo em torno da Constituinte exemplifica bem a luta pelo reconhecimento como sujeito político e cidadáo pleno. Inúmeras escolhas refletiam o ceticismo de boa parte da população e dos militantes sobre as capacidades efetivas de fazerem suas vozes serem ouvidas. Houve um longo processo, permeado de sucessivas caravanas a Brasília, em que as lideranças e os militantes passaram a se autorreconhecer como parte do processo constituinte.

No início das mobilizaçóes, antes das eleiçóes, impunha-se a escolha entre uma atuaçáo paralela à Constituinte e a tentativa de influenciar diretamente algumas pautas. $\mathrm{O}$ mecanismo das emendas populares serviu para unificar e ampliar a ação coletiva na pressão direta aos constituintes. O processo de elaboração das emendas também foi, em muitos casos, disputado entre os que desejavam alguns avanços concretos e aqueles que avaliavam que o melhor caminho seria mostrar à sociedade quais eram os avanços ideais.

Não importa fazer aqui um julgamento sobre quais caminhos estavam certos ou errados, até porque certamente a resposta varia de caso a caso, mas o que é essencial é perceber que, ao longo da mobilização, os movimentos sociais se redefiniram internamente e externamente: nas pautas, estratégias, identidades, articulaçóes com outros movimentos, no relacionamento com a mídia, nos contatos e negociações com políticos e partidos, e, finalmente, nas relação com a própria sociedade.

protesto seriam a existência de conflito acirrado com uma amplitude setorial e geográfica, assim como o surgimento de novas organizaçôes de movimentos sociais e o "empoderamento" (empowerment) de velhos movimentos, a criação de novos "enquadramentos globais" ( master frames) de significados e a invençáo de novas formas de ação coletiva (Cf. TARROW, 1995, pp. 9I-92). 
É importante analisar que, paradoxalmente, a mesma dinâmica que dificultou a criação de projetos e visốes globais de uma Constituição foi a que contribuiu significativamente para que os movimentos e as emendas populares pudessem ter alguma influência no texto final. De fato, os trabalhos na Constituinte se caracterizaram por alto grau de descentralizaçâa. Com a exceção do Partido dos Trabalhadores (com um projeto escrito pelo jurista Fábio Konder Comparato), os partidos políticos com representação na Câmara e no Senado não apresentaram projetos de Constituição discutidos com as próprias bases (eleitorais ou parlamentares); mesmo o anteprojeto da Comissáo Provisória de Estudos Constitucionais ("Comissão Afonso Arinos"), convocada pelo governo Sarney antes da Constituinte e cujos resultados foram criticados pelos setores conservadores, não foi oficialmente encaminhada para a Assembleia Nacional Constituinte e tampouco se tornou texto-base para a futura Constituição, embora tivera uma influência significativa nos debates que aconteceram.

Dessa forma, a elaboração do texto constitucional foi realizada inicialmente a partir de 24 subcomissóes, dentro das quais, segundo o art. I4 do Regimento Interno da ANC, entre cinco e oito reuniôes das subcomissóes teriam de ser destinadas à audiências de entidades representativas de segmentos da sociedade. As propostas dos parlamentares, das entidades e dos especialistas ouvidos foram consolidadas e enviadas para oito Comissóes Temáticas, cada qual agregando três subcomissóes. Em seguida, uma Comissão de Sistematização elaboraria o anteprojeto a ser votado em dois turnos pelo plenário da Assembleia Nacional Constituinte, com direito à apresentação de emendas.

As emendas populares eram apresentadas diretamente à Comissão de Sistematização (embora seu conteúdo tenha sido, na maioria dos casos, apresentado previamente pelas entidades nas audiências públicas das subcomissōes). Caso a Comissão de Sistematização se manifestasse contrária a uma emenda popular, caberia às entidades um recurso no Plenário, desde que interposto por cinquenta e seis constituintes.

A descentralizaçáo dos trabalhos constituintes permitiu maior participação e influência (positiva e negativa) tanto dos deputados não ligados às elites partidárias quanto dos próprios movimentos sociais. Assim, embora tenham sido muitas as derrotas, também se tornaram possíveis algumas conquistas pontuais, inclusive no Projeto-A votado pela Comissão de Sistematização. No entanto, a reação às influências dos setores progressistas da esquerda e do PMDB veio com a formação do "Centrão" (composto por parlamentares de parte do PMDB com parlamentares do PFL, PDS e PL), que aprovou, no dia 5 de janeiro de 1988, um novo Regimento Interno invertendo o ônus de se ter a maioria ( 280 votos) para a manutençáo de qualquer trecho do Projeto-A da Comissão de Sistematizaçáo (considerado progressista demais para a maioria conservadora da ANC) $)^{\mathrm{r}}$.

Assim, grande parte das conquistas asseguradas no primeiro Anteprojeto de Constituição pôde ser facilmente descartada pelo "Centrão" no Plenário.

Io No primeiro Regimento Interno, o ônus dos duzentos e oitenta votos recaía sobre quem quisesse alterar algum trecho do Projeto-A. 


\section{CONCLUSÃO: AVANÇOS E LIMITES DA NOVA CARTA MAGNA}

Apesar das barreiras impostas pela correlação de forças e pela formaçáo do "Centrão", a nova Carta Magna avançou significativamente na consolidação de alguns direitos civis, políticos e sociais. Embora não seja o objetivo deste trabalho realizar análise completa do rol de direitos incluídos na Constituição de 1988, apresentam-se aqui algumas conquistas cruciais, muitas das quais se originaram ou foram apoiadas por emendas populares.

$\mathrm{O}$ art. $5^{\circ} \mathrm{da}$ Constituição, que trata dos direitos e deveres individuais e coletivos, enumera uma série de direitos humanos, proibindo a tortura e o tratamento desumano ou degradante, assim como classificando como inviolável a liberdade de consciência e de crença e assegurando aos presos o respeito à integridade física e moral. A seguir são apresentadas algumas das outras garantias formais asseguradas no art. $5^{\circ}$ :

\section{ALGUMAS GARANTIAS FORMAIS NO ART. 5 DA CONSTITUIÇÃO'1":}

- Inciso XXI - Atribuiçáo de Competências a Associaçóes para a Defesa de Direitos Individuais: "as entidades associativas, quando expressamente autorizadas, têm legitimidade para representar seus filiados judicial ou extrajudicialmente" (Dallari, 2001, p. 65) ${ }^{12}$.

- Inciso XXXIV - Direitos de Petiçáo e Representaçáo: “(...) permitem a qualquer pessoa dirigir-se a uma autoridade, pedindo providências para a defesa de direitos ou contra ilegalidade ou abuso de poder" (Dallari, 2001 p. 64).

- Inciso LXVIII: Mantido o Habeas Corpus: concedido sempre que alguém sofrer ou se achar ameaçado de sofrer violência ou coaçáo em sua liberdade de locomoçáo, por ilegalidade ou abuso de poder (é usado, sobretudo, para assegurar a liberdade em casos de prisáo ilegal ou de sua ameaça).

- Inciso LXIX - Mandado de Segurança: suspende a aplicação de um ato ilegal, de qualquer autoridade, que ofenda direito líquido e certo de uma pessoa física ou jurídica.

- Inciso LXX - Mandado de Segurança Coletivo: permite que um partido político, uma organização sindical, uma entidade de classe ou uma associação legalmente constituída defendam os direitos de seus membros.

II Conforme Brasil (1990).

I2 Dalmo Dallari pondera a importância desse direito a partir da análise de que as "pessoas mais pobres não têm o hábito de utilizar o Poder Judiciário para defender seus direitos, ou por falta de informaçôes, ou por não conseguirem o auxílio de um advogado, ou ainda por terem medo de uma represália. $\mathrm{O}$ número de associaçôes cresceu muito no Brasil nos últimos anos e por meio delas será mais fácil e menos perigoso chegar ao juiz para repelir uma agressão a direitos ou para obter a garantia de proteção judicial para um direito negado ou ameaçado" (DALLARI, 200I, p. 65). 
- Inciso LXXI - Mandado de Injunçáo: concedido "sempre que a falta de norma regulamentadora torne inviável o exercício dos direitos e liberdades constitucionais e das prerrogativas inerentes à nacionalidade, à soberania e à cidadania”.

- Inciso LXXII - Habeas Data: permite a uma pessoa saber que informaçóes constam a seu respeito em qualquer banco de dados de entidades governamentais ou que tenham caráter público.

- Inciso LXXIII - Açáo Popular:

Por meio de ação popular qualquer cidadão é parte legítima para pedir ao juiz a anulaçáo de ato lesivo ao patrimônio público ou de entidade de que o Estado participe. A inovação [de 1988] está na possibilidade de ação popular para anulaçáo de atos que sejam lesivos à moralidade administrativa, ao meio ambiente e ao patrimônio histórico e cultural (DALlaRI, 20OI, p. 64).

Já na seção dos Princípios Fundamentais, no art. $\mathrm{I}^{\circ}$, Parágrafo Único, a Constituição da República Federativa do Brasil afirma: "Todo o poder emana do povo, que o exerce por meio de representantes eleitos ou diretamente, nos termos desta Constituição (grifo colocado)", palavra essencial para possibilitar a legalidade e legitimidade dos mecanismos de participação direta presentes na nova Carta Magna.

Já no art. I4: "A soberania popular será exercida pelo sufrágio universal e pelo voto direto e secreto, com valor igual para todos, e, nos termos da lei, mediante: I - plebiscito; II - referendo; III - iniciativa popular”. Dessa forma, pela primeira vez no Brasil, a Constituição Federal articulou a democracia representativa com elementos da democracia direta (como a iniciativa legislativa, o referendo e o plebiscito).

A previsão expressa da democracia direta, ao lado da forma representativa. Isso constitui um avanço importante, pois inúmeras vezes foi recusada a participação direta ou semidireta do povo, sob a alegaçấo de que a Constituição definia o Brasil como democracia representativa e por isso o povo só poderia participar através de representantes (Dallari, 1989, p. 384).

De fato, os mecanismos de participação política direta foram um dos temas centrais da campanha dos movimentos sociais antes e durante a Assembleia Nacional Constituinte, com intensa articulação entre as lideranças sociais e os deputados constituintes. Foram três emendas populares que trataram sobre o tema da participaçáo popular, as de no . 02I, 022 e 056, reunindo, em conjunto, 367.301 assinaturas.

No entanto, um dos centros de disputa dos artigos relativos à iniciativa popular foi a porcentagem de assinaturas de eleitores necessária à apresentação de uma iniciativa. A porcentagem final acabou sendo bem mais restritiva, exigindo, para apenas se originar, um número muito mais 
elevado do que aquelas trinta mil assinaturas necessárias para apresentar uma emenda popular na Constituinte.

No plano federal, o art. 6I, $\$ 2^{\circ}$, estabeleceu um mínimo de I\% do eleitorado nacional (o que representaria, em 2008, I.304.696 assinaturas distribuídas por pelo menos cinco estados, com não menos de três décimos por cento dos eleitores de cada um deles $\left.{ }^{13}\right)$. No plano estadual, cada Assembleia Legislativa tem a autonomia para dispor em lei sobre a iniciativa popular no processo legislativo estadual (BRASIL, 1990). Finalmente, no caso das iniciativas populares nos municípios ou nos bairros, a barreira é de pelo menos $5 \%$ do eleitorado ((BrasIL, I990). Para Moisés (1990, p. 86):

Autores como Benevides têm razáo em creditar a dificuldade representada por um piso eleitoral táo elevado como requisito da iniciativa à vitória dos setores conservadores no Congresso Constituinte: afinal, foi o Centrão que não aceitou a proposta da Comissão de Sistematização que estabelecia uma exigência mínima de 0,3\% (três décimos por cento) para a iniciativa popular legislativa. Registra-se, aliás, que, nesse particular, a proposta da Comissão de Sistematização era até mais avançada que o anteprojeto apresentado pelo PT que previa a exigência de $0,5 \%$ do eleitorado para a apresentação da iniciativa.

No caso das emendas populares, em um momento de intensa mobilizaçáo, das cento e vinte e duas emendas, apenas seis obtiveram mais de quinhentas mil assinaturas ${ }^{14}$, sendo que cinco dessas emendas foram patrocinadas por entidades religiosas (especialmente a CNBB e a Comissão Pastoral da Terra).

Em relaçáo aos outros instrumentos, o art. 49, inciso XV relega ao Congresso Nacional a competência exclusiva de autorizar referendo e convocar plebiscito (BrasIL, I990). Além disso, os mecanismos de participação popular presentes na Constituinte de 1988 possuem duas outras limitaçóes: a impossibilidade de usar esses mecanismos para gerar modificaçóes no texto constitucional e a impossibilidade de usar o referendo e a iniciativa popular (em plano federal) para vetar ou propor a rejeiçáo de lei ou norma que gere ou contrarie os interesses dos cidadáos.

Ao restringir os mecanismos às leis ordinárias, a primeira limitaçáo segue na contramão da legislação de países como a Suíça e de vários estados norte-americanos, em que o eleitor comum pode introduzir diretamente modificaçôes no texto constitucional; o que seria, segundo José Álvaro Moisés, "um importante instrumento de ampliaçâo do conceito de cidadania que, dessa

I3 Nas eleições de 2008, o Tribunal Superior Eleitoral registrou 130.469.549 eleitores (Fonte: www.tse.gov.br).

I4 Emendas com mais de quinhentas mil assinaturas e entidades responsáveis:

No. oIo (Ensino Particular): 750.077 assinaturas - CNBB/AEC/ABESC.

No. oII (Família/Contra o aborto): 516.000 assinaturas - CNBB/AEC/Cáritas.

No. 052 (Reforma Agrária): 638.469 assinaturas - ConTAG/ABRA/CPT.

No. 053 (Reforma Agrária): 550.000 assinaturas - CUT /MST/CPT.

No. 054 (Direitos do Trabalhador): 743.718 assinaturas - CUT/MST/CPT.

No. 068 (Preservação do "Sistema S" - Sesi/Senai/Sesc/Senac): 628.238 assinaturas - CNTC/Senac/Sesc. 
forma, expande-se para o terreno da própria produção do direito" (Morsés, 1990, p. 7), atingindo, assim, o núcleo dos ordenamentos que definem o sistema político. Já a segunda limitação também seria igualmente importante para o controle social do poder por parte dos cidadáos; caso o poder de veto popular tivesse sido adotado, ele seria um importante mecanismo para prevenir que os interesses de amplos setores da sociedade fossem contrariados por alguma legislatura.

Apesar das limitaçóes dos mecanismos de participação popular, é possível indagar se a mesma mudança observada na atuação dos parlamentares para com os movimentos populares organizados ao longo do Congresso Constituinte (cada vez mais negociando e debatendo com as lideranças sociais) também não poderia acontecer a partir do uso cotidiano desses mecanismos:

Sob a ameaça de pressão dos instrumentos da legislação direta, os parlamentos funcionam melhor e, além disso, eles próprios tomam a iniciativa de submeter a referendo popular leis que são da sua responsabilidade. Isso articula os efeitos da participação direta com as funçōes da representação, tornando essa última mais ágil, mais eficaz e, principalmente, mais adequada às demandas contemporâneas da sociedade (MoIsÉs, I990, p. 89).

A Constituiçáo de 1988 também assegurou a autonomia formal do movimento sindical em face do Estado (art. 8), assim como o direito de greve (art. 9), ambas conquistas essenciais para as mobilizaçóes sociais subsequentes. Além disso, um dos principais avanços da Carta de 1988 no que tange à ampliação dos direitos políticos é a extensáo do sufrágio facultativo aos brasileiros de dezesseis ou mais anos de idade, assim como a extensão do sufrágio aos analfabetos (com direito de votar, mas não de serem votados).

Sobre essa expansão do sufrágio aos analfabetos, cabe relembrar a discussão anterior sobre a subcidadania no Brasil e sobre a ralé estrutural, caracterizada por um "habitus precário", em que os analfabetos estão entre as principais vítimas. A extensão do sufrágio a essa parcela sistematicamente excluída foi, certamente, um passo importante na incorporaçáo dessa populaçáo marginalizada. Os mecanismos de participação popular conquistados, apesar das insuficiências significativas e das dificuldades de organizaçáo, fazem parte ativa dos caminhos para que os interesses dos movimentos sociais sejam ouvidos e interfiram diretamente nos centros de poder político. Assim, tanto os movimentos quanto os mecanismos de participação popular foram e ainda são instrumentos privilegiados na luta pela expansão da cidadania no Brasil.

Em um momento histórico delicado, com uma correlação de forças contrária aos interesses dos movimentos populares, a Constituinte de 1988 representou uma mudança significativa na cultura política nacional. Assim, relembrando o esquema de Bryan Turner apresentado no início, com base nessa experiência-chave da redemocratização, torna-se impossível classificar a cidadania no Brasil como uma chave puramente passiva. Certamente a influência popular foi aquém do desejado, mas conquistou marcos históricos na Carta Magna, que, em conjunto com o aprendizado dos movimentos sociais ao longo do processo, abre a possibilidade cotidiana de que, em novos ciclos de mobilizaçáo, surjam novas lutas coletivas em prol da cidadania plena. 


\section{REFERÊNCIAS BIBLIOGRÁFICAS}

Arns, Paulo Evaristo. Contribuição da Igreja. In: SADER, Emir (Org.). Constituinte e democracia no Brasil hoje. São Paulo: Editora Brasiliense, 1985.

Brasıl. Constituição 1988. Constituição da República Federativa do Brasil: promulgada em 5 de outubro de 1988. Organização Juarez de Oliveira. 4. ed. São Paulo: Saraiva, 1990.

Dallari, Dalmo de Abreu. A participação popular e suas conquistas. In: Michiles, Carlos et. al. Cidadão constituinte: a saga das emendas populares. Rio de Janeiro: Paz e Terra, 1989.

Os direitos fundamentais na Constituição Brasileira. In: GRAU, Eros Roberto; FIOCCA, Demian (Org.). Debates sobre a Constituição de 1988. São Paulo: Ed. Paz e Terra, 2001.

Diário da Assembléia Nacional Constituinte. Resolução no 2 de 1987. Dispóe sobre Regimento Interno da Assembléia Nacional Constituinte. Brasília, Ano I, n. 33, quartafeira, 25 de março de 1987.

Teorias dos movimentos sociais: paradigmas clássicos e contemporâneos. 5. ed. São Paulo: Loyola, 2006.

Honneth, Axel. Luta por reconhecimento - A gramática moral dos conflitos sociais. São Paulo: Ed. 34, 2003.

Marshall, T. H. [1949]. Cidadania, classe social e status. Rio de Janeiro: Zahar, 1967.

Michiles, Carlos et al. Cidadão constituinte: a saga das emendas populares. Rio de Janeiro: Paz e Terra, 1989.

Moısés, José Álvaro. Cidadania e participação: ensaio sobre o plebiscito, o referendo e a iniciativa popular na nova Constituição. São Paulo: Marco Zero \& Cedec, 1990.

Quirino, Célia Galvão; Montes, Maria Lúcia. Constituições. São Paulo: Ed. Ática, 1986. . Constituições brasileiras e cidadania. São Paulo: Ed. Ática, 1987. p. 80.

SAder, Emir. Democracia, socialismo e anticapitalismo. In: Fortes, Luiz Roberto Salinas; Nascimento, Milton Meira do (Org.). Quando novos personagens entraram em cena: experiências, falas e lutas dos trabalhadores da Grande São Paulo, 1970-1980. Rio de Janeiro: Paz e Terra, 1988.

SAntos, José Maria. A politica geral do Brasil. São Paulo: J. Magalhães, 1930. p. 217.

Souza, Jessé. A construção social da subcidadania: para uma Sociologia política da modernidade periférica. Rio de Janeiro: Iuperj, 2003. 
SouzA, João Almino de. O processo político da Constituinte de 1987. In: ForTes, Luiz Roberto Salinas; Nascimento, Milton Meira do (Org.). A Constituinte em debate. Sáo Paulo: SOFIA Editora; Seaf, 1987. (Colóquio realizado entre 12 e 16 de maio de 1986.)

TARrow, Sidney. Cycles of collective action: between moments of madness and the repertoire of contention. In: Traugott, Mark (Org.). Repertoires and cycles of collective action. Durham: Duke University Press, 1995.

Tilly, Charles. From mobilization to revolution. Menlo Park: Addison-Wesley Publishing Company, 1978.

Turner, Bryan S. Outline of a theory of citizenship. In: Turner, Bryan S.; Hamilton, Peter (Ed.). Citizenship: critical concepts. London; New York: Routledge, 1994.

\section{BIBLIOGRAFIA}

Barroso, Pérsio Henrique. Constituinte e Constituição: participação popular e eficácia constitucional (1987-1997). 1997. Tese (Mestrado em Direito) - Universidade Federal de Santa Catarina, Florianópolis, 1997.

Bulmer, Martin; Rees, Anthony M. Citizenship today: the contemporary relevance of T.H. Marshall. London: UCL Press, 1996.

Cardoso, Ruth. Movimentos sociais urbanos: balanço crítico. In: Almeida, Maria H. T.; SorJ, Bernardo. Sociedade e política no Brasil pós-64. São Paulo: Brasiliense, 1983.

. Os movimentos sociais na América Latina. Revista Brasileira de Ciências Sociais, São Paulo, v. 1, n. 3, 1987.

. Movimentos populares no contexto da consolidação democrática. In: Reis, Fábio W.;

O’donnel, G. (Org.). A democracia no Brasil-dilemas e perspectivas. São Paulo: Vértice, 1988.

Carvalho, José Murilo de. Cidadania no Brasil - O longo caminho. Rio de Janeiro: Civilização Brasileira, 2001.

Comissão de Sistematização da Assembléia Nacional Constituinte. Emendas Populares. Brasília: Centro Gráfico do Senado Federal, agosto 1987. v. 1 e 2.

Enrenberg, John. Civil society: a critical history of an idea. New York: University Press, 1999.

Fortes, Luiz Roberto Salinas; Nascimento, Milton Meira do (Org.). A Constituinte em debate. São Paulo: Sofia Editora; Seaf, 1987. (Colóquio realizado entre 12 e 16 de maio de 1986.)

Gohn, M. G. M. Novas teorias dos movimentos sociais. São Paulo: Ed. Loyola, 2008. 
Gomes, Sandra. O impacto das regras de organização do processo legislativo no comportamento dos parlamentares - Um estudo de caso da Assembléia Nacional Constituinte (1987-1988). DADOS - Revista de Ciências Sociais, Rio de Janeiro, v. 49, n. 1, pp. 193 a 224, 2006.

Hall, John A. A search of civil society. In: Hall, John A. Civil Society, theory, history, comparison. Cambridge: Cambridge Polity Press, 1995.

Intervozes. Vozes da democracia: histórias da comunicação na redemocratização do Brasil. São Paulo: Imprensa Oficial do Estado de São Paulo \& Intervozes - Coletivo Brasil de Comunicação Social, 2006.

Keane, John. Despotism and democracy. In: Keane, John (Ed.). Civil and the state. London: Verso, 1988.

Remembering the dead. In: Keane, John. Democracy and civil society. London: New York, 1988.

Kowarick, Lúcio. Movimentos sociais urbanos no Brasil contemporâneo: uma análise da literatura. Revista Brasileira de Ciências Sociais, São Paulo, v. 1, n. 3,1987.

A espoliação urbana. Rio de Janeiro: Paz e Terra, 1979.

Kymlicka, Will; Norman, Wayne. El retorno del ciudadano: una revisión de la producción reciente en teoría de da ciudadanía. Cuadernos del CLAEH, Montevideo, n. 75, pp. 81-112, 1996.

Melucci, Alberto. A invenção do presente - Movimentos sociais nas sociedades complexas. Petrópolis: Vozes, 2001.

. O jogo do eu. São Leopoldo: Unisinos, 2004.

SAder, Emir (Org.). Constituinte e democracia no Brasil hoje. São Paulo: Editora Brasiliense, 1985.

Nascimento, Milton Meira do (Org.). A Constituinte em debate. São Paulo: Sofia Editora; Seaf, 1987. (Colóquio realizado entre 12 e 16 de maio de 1986.) p. 48.

Tavolaro, Sergio B. F. Quando discursos e oportunidades políticas se encontram: para repensar a Sociologia política da cidadania moderna. Novos Estudos Cebrap, São Paulo, n. 81, pp. 117-136, julho 2008 .

Tilly, Charles. Models and reality of popular collective action. Social Research, v. 52, n. 2, 1985. Social movements as historically specific cluster of political performances. Berkeley Journal of Sociology: A Critical Review, v. XXXVIII, pp. 1-30, 1993-1994.

Tourraine, A. An introdution to the study of social movements. Social Research, v. 52, n. 4, 1985. 
. Os novos conflitos sociais: para evitar mal-entendidos. Lua Nova, São Paulo, n. 17, pp. 5-18, 1989.

Turner, Bryan S.; Isın, Engin F. Handbook of citizenship studies. London: Sage, 2002. 